\title{
Caught in the Middle? The Economics of Middle-Income Traps
}

DOI:

10.1111/joes. 12175

\section{Document Version}

Accepted author manuscript

Link to publication record in Manchester Research Explorer

\section{Citation for published version (APA):}

Agenor, P-R. (2017). Caught in the Middle? The Economics of Middle-Income Traps. Journal of Economic Surveys, 771-91. https://doi.org/10.1111/joes.12175

\section{Published in:}

Journal of Economic Surveys

\section{Citing this paper}

Please note that where the full-text provided on Manchester Research Explorer is the Author Accepted Manuscript or Proof version this may differ from the final Published version. If citing, it is advised that you check and use the publisher's definitive version.

\section{General rights}

Copyright and moral rights for the publications made accessible in the Research Explorer are retained by the authors and/or other copyright owners and it is a condition of accessing publications that users recognise and abide by the legal requirements associated with these rights.

\section{Takedown policy}

If you believe that this document breaches copyright please refer to the University of Manchester's Takedown Procedures [http://man.ac.uk/04Y6Bo] or contact uml.scholarlycommunications@manchester.ac.uk providing relevant details, so we can investigate your claim.

\section{OPEN ACCESS}




\title{
Caught in the Middle? The Economics of Middle-Income Traps
}

\author{
Pierre-Richard Agénor* \\ Final version: June 5, 2016 \\ Forthcoming, Journal of Economic Surveys
}

\begin{abstract}
This paper provides an overview of the recent analytical and empirical literature on middle-income traps. The first part examines the descriptive and statistical evidence on these traps. The second discusses the various arguments that have been put forward to explain the existence, and persistence, of middle-income traps. These arguments include diminishing returns to physical capital, exhaustion of cheap labor and imitation gains, insufficient quality of human capital, inadequate contract enforcement and intellectual property protection, distorted incentives and misallocation of talent, lack of access to advanced infrastructure, and lack of access to finance, especially in the form of venture capital. The third part considers public policies aimed at avoiding, and escaping from, middleincome traps. The concluding part identifies a number of directions in which the empirical and theoretical literature could fruitfully evolve.
\end{abstract}

JEL Classification Numbers: H54, O31, O41.

${ }^{*}$ Hallsworth Professor of International Macroeconomics and Development Economics, School of Social Sciences, University of Manchester; co-Director, Centre for Growth and Business Cycle Research; and Senior Fellow, FERDI. I would like to thank, without implication, Raouf Boucekkine, Cecilia Garcia-Peñalosa, Patrick Guillaumont, two anonymous referees and participants at several seminars for helpful discussions and comments on a previous draft. A more detailed version of this paper is available upon request. 


\section{Introduction}

Since the 1950s, rapid growth has allowed a significant number of countries to achieve middle-income status. However, very few have made the additional leap needed to become high-income economies. ${ }^{1}$ Rather, many have gotten stuck in what has been called a middle-income trap (a term apparently coined by Gill, Kharas, et al. (2007)), generally characterized by a sharp deceleration in growth, following a period of sustained increases in per capita income.

Much of the initial discussion on middle-income traps has focused on the experience of Latin America, the Middle East and North Africa, and especially East Asia. The recent slowdown in economic growth in China has also revived the debate on what causes middle-income traps and what type of policies can help to avoid them or escape from them once a country has fallen into one. Indeed, some observers have argued that aging population, rising dependency rates, and increasing labor costs have reduced China's comparative advantage in a wide range of labor-intensive production activities, while the country is still improving its capacity to compete on knowledgeand technology-intensive industries. As a result, there have been heightened concerns about a sustained economic slowdown and the possibility that the country may be trapped in a middle-income stage.

This paper provides an overview of the recent analytical and empirical literature on middle-income traps. From an analytical standpoint, the perspective adopted here is that, rather than slow (or lack of) convergence to a unique equilibrium due to cross-country differences in structural parameters and public policies, as emphasized in the conventional literature on growth empirics (see Agénor (2004) and Acemoglu (2009) for instance), a middle-income trap is best viewed as a "bad" equilibrium among many - bad but nonetheless stable, in the sense of being a persistent state to which the economy gravitates unless some significant shock, structural or otherwise, occurs. ${ }^{2}$

\footnotetext{
1 "Middle income economies" and "high income economies" are usually defined in accordance with the World Bank's classifications by income group, as described on the Bank's website at http://data.worldbank.org/about/country-classifications. It is worth noting that the official World Bank threshold for "high-income economy" is substantially lower than US or OECD income averages and that the classification scheme has important operational implications - most notably in terms of access to concessional financing for those countries that are considered low income.

${ }^{2}$ Put differently, in the conventional approach to growth convergence, countries that share the same
} 
This perspective also has important implications for understanding the role of public policy in helping to escape from a middle-income trap.

The remainder of the paper is organized as follows. Section 2 examines the descriptive and statistical evidence on these traps. Section 3 discusses the various arguments that have been offered to explain the existence, and persistence, of middle-income traps. These arguments include, in addition to diminishing returns to physical capital and unskilled labor, poor quality of human capital, distorted incentives and misallocation of talent, and lack of access to advanced infrastructure and finance. At the outset, an analytical distinction between middle-income traps and the more common notion of poverty traps - generally defined as self-reinforcing mechanisms that cause poverty to persist - is also provided. Section 4 considers a range of public policies aimed at escaping from a middle-income trap. To a significant extent, these policies are directly related to, or motivated by, the causes highlighted in the preceding section. The link between the debate on escaping from middle-income traps and the process - or lack thereof - of industrial transformation is also highlighted. The concluding section identifies a number of directions in which the empirical and theoretical literature could fruitfully evolve.

\section{Caught in the Middle? The Evidence}

The evidence on middle-income traps is based on both descriptive contributions and formal econometric studies. In both cases, assessing whether a country is caught in a middle-income trap requires at the outset a measure of (absolute or relative) income per capita.

The most common classification of income categories for countries is by the World Bank, which ranks countries based on their absolute level of gross national income (GNI) per capita. The current (May 2016) classification of the World Bank defines low-income countries as those with GNI per capita of $\$ 1,045$ or less in 2014; lower middle-income those with GNI per capita above $\$ 1,045$ but less than $\$ 4,125$; upper

characteristics eventually reach the same unique equilibrium and the same growth rate. By contrast, in models with multiple equilibria, two countries that are otherwise identical may converge to different growth rates, depending only on their initial conditions. 
middle-income those with GNI per capita above $\$ 4,125$ but less than $\$ 12,736$; and high-income those with GNI per capita of $\$ 12,736$ or more. ${ }^{3}$ These rankings are revised at regular intervals (mainly to determine the lending eligibility of each country), based on inflation and exchange rate changes. For instance, if a country graduates today to high-income status but fails to grow at the average growth rate in that group over a sufficiently long period of time, it may fall back into the middle-income group. This, in fact, has happened on a number of occasions. Fundamentally, however, the World Bank classification is in real (or absolute) terms. Using thresholds that are constant over time implies that a country's status is independent of the status of other countries. In turn, this means that there is no preset distribution that specifies the proportion of countries in each category.

An alternative approach to defining income categories is based on a relative measure, usually domestic per capita income relative to the United States, another developed country, or a group of developed countries. Athukorala and Woo (2011) for instance define a Catch-Up Index (CUI), in terms of each country's per capita GDP in percentage of the US level of per capita GDP. A CUI higher than 55 percent defines high-income countries, a CUI between 20 percent and 55 percent defines middle-income countries, and a CUI lower than 20 percent defines low-income economies.

The relative approach is often considered as more appropriate when the focus is on analyzing absolute convergence or catching up, whereas the absolute approach is more relevant when the goal is to understand why some countries enter a sustained period of stagnation (Im and Rosenblatt (2013)). The key point of the first approach is that becoming high income is a moving target. It is not sufficient to grow at high rates, even during significant periods of time; growth must also occur at rates that are relatively higher than in those countries that are already considered as high income. However, both approaches are subject to the limitation that they rely on somewhat arbitrary

\footnotetext{
${ }^{3}$ See http://data.worldbank.org/about/country-and-lending-groups. This classification is based on the Atlas method, which uses a conversion factor instead of current exchange rates to measure GNI across countries, in order to mitigate changes to the exchange rate caused by inflation. For any given year, this conversion factor is the average of a country's official exchange rate for that year and its exchange rates for the two preceding years, adjusted for the difference between the rate of inflation in the country and international inflation. A key limitation of this method, however, is that official exchange rates may not fully reflect market-based exchange rates.
} 
assumptions to define thresholds. As a result, there may be significant differences in the thresholds obtained within the two groups of studies based on either absolute or relative measures - and thus substantial variations in empirical results within and across groups.

\subsection{Descriptive Studies}

Descriptive studies on middle-income traps include broad cross-country comparisons by the World Bank (2012) and more specific country studies such as Hill et al. (2012), Flaaen et al. (2014), Agénor and El Aynaoui (2015), and Cherif and Hasanov (2015). According to the World Bank (2012) for instance, of 101 middle-income economies in 1960, only 13 had become high income by 2008: Equatorial Guinea, Greece, Hong Kong, Ireland, Israel, Japan, Mauritius, Portugal, Puerto Rico, Singapore, South Korea, Spain, and Taiwan. The so-called Asian tigers (Hong Kong, Singapore, South Korea, and Taiwan), in particular, moved from low-margin, labor-intensive goods such as clothing and toys to electronics assembly, then on to component manufacture and, in the case of South Korea and Taiwan, to advanced manufacturing, design and management. By contrast, most countries in Latin America, as well as in the Middle East and North Africa, reached middle-income status during the 1960s and 1970s, and have remained there ever since.

In Asia, Malaysia and Thailand provide also good examples of the growth slowdown that typically characterizes a middle-income trap. Despite the financial crisis of 199798, they both ended the last century with productivity levels that stood significantly closer to those recorded in advanced countries. Between 1970 and 2010, Malaysia recorded the largest improvement in educational attainment among the Asian tigers6 years, compared to 5.4 for South Korea (Lee and Francisco (2012, Table 1)). However, the pattern of labor-intensive production and exports in these countries has remained broadly unchanged for the past two decades. At the same time, they have faced growing competition from low-cost producers, first China and India, and more recently Vietnam and Cambodia. Growth has slowed significantly as a result. After growing at an annual average rate of 5.2 percent per capita during the period 1970-79, growth in Malaysia slowed to 3.8 percent during the period 1980-99 and to 3.0 percent during 
2000-10 (Hill et al. (2012, Table 2). In Thailand, the annual growth rate per capita slowed from an average of 5.3 percent during 1970-89 to 4.1 percent during 1990-99 and 3.4 percent during 2000-10 (Hill et al., op. cit.). To many observers, the inability of middle-income economies such as Malaysia and Thailand to induce a shift in their industrial and export structure appears to reflect the failure in developing enough capacity to meet the needs of fast-evolving international product markets where the emphasis is on innovation and product differentiation. Middle-income countries may end up being caught between low-wage poor countries, dominant in mature industries, and innovative rich countries, dominant in technology-intensive industries. The reason is that low-income economies tend to have a comparative advantage in labor-intensive industries, whereas high-income economies have a comparative advantage in capitalintensive and technology-intensive industries.

The inability to move up the "value chain" and resume rapid growth by breaking into fast-growing markets for knowledge and innovation-based products and services has indeed remained elusive not only for Malaysia and Thailand but also for a number of other middle-income countries, like Brazil (see OECD (2014)). From 1965 to 1980, Brazil showed stable growth at a yearly average rate of 5.6 percent per capita, fairly similar to the average annual growth rate of 6.5 percent experience by South Korea between 1965 and 1986 (Kharas and Gertz (2010)). However, while South Korea was able to continue to grow at sustained rates (at an annual rate of about 5.5 percent per capita for another twenty years) and achieve an innovation-based economy, maintaining rapid growth in per capita income in Brazil has proved difficult. With growth rates per capita averaging 0.7 percent per annum between 1980 and 2012, today per capita incomes are only slightly higher than they were thirty years ago. In fact, compared to OECD averages, in 2012 GDP per capita in Brazil was back to where it was in 1960 (OECD (2014, Table 6.9)), around 34 percent.

\subsection{Econometric Evidence}

More formal econometric analysis of whether a country is stuck in a middle-income trap - based on either the absolute or the relative approach to defining income categories is provided by Eichengreen et al. (2012, 2014), Felipe et al. (2012, 2014), Jimenez et 
al. (2012), Aiyar et al. (2013), Im and Rosenblatt (2013), and Ye and Robertson (2015). ${ }^{4}$ The key idea has been to identify, using either rigorous econometric techniques or simple criteria, statistically significant breaks or turning points in time-series data on levels or growth rates in per capita incomes across countries.

Using the latter approach, Eichengreen et al. (2012) defined a growth slowdown based on three conditions. The first requires that prior to the slowdown the sevenyear average growth rate is 3.5 percent per annum or greater. The second identifies a growth slowdown with a decline in the seven-year average growth rate by at least 2 percentage points. The third limits slowdowns to cases in which per capita GDP is greater than $\$ 10,000$ in 2005 constant international PPP prices - thereby ruling out episodes related to countries that have not yet successfully developed. Based on these criteria, they found that growth slowdowns typically occur at per capita incomes of about $\$ 15,000$ at 2005 prices. At that point, the growth rate of GDP per capita slows by an average of 3.5 percentage points. ${ }^{5}$ They also found, using regression and standard growth accounting techniques, that growth slowdowns are essentially productivity slowdowns - with a drop in total factor productivity (TFP) growth representing about 86 percent, or 3 percentage points, of the absolute reduction in the growth rate of GDP per capita - and that the peak probability of a growth slowdown occurs when manufacturing accounts for about 23 percent of total employment in the economy. Aiyar et al. (2013) also found that steep falls in TFP growth were major factors in the growth slowdown experienced by a number of countries, especially in Latin America.

In a subsequent study, Eichengreen et al. (2014) searched for structural breaks by applying a Chow test to a sample of formerly fast growing middle-income countries. Their analysis showed that the likelihood of sudden slowdowns is bimodal, having its peaks in the range of $\$ 10,000-\$ 11,000$ in 2005 PPP US dollars at and in the higher interval of $\$ 15,000-\$ 16,000$ constant prices. This evidence seems to suggest therefore that a large group of middle-income countries is at risk of being caught up a trap.

\footnotetext{
${ }^{4} \mathrm{Im}$ and Rosenblatt (2013) also provide a review of some of the empirical literature. In some of these studies data on per capita income are taken from the Penn World Tables, available at http://www.rug.nl/research/ggdc/data/pwt/?lang=en

${ }^{5}$ However, the authors also note that there is considerable dispersion in the income levels at which growth slowdowns occur.
} 
The analysis in Eichengreen et al. $(2012,2014)$ can be criticized on three grounds (Im and Rosenblatt (2013)). First, the threshold at which a slowdown tends to occur is at a level that would probably correspond anyway to a high-income country by World Bank standards, depending upon the PPP adjustment factor involved. Second, a slowdown by two percentage points in per capita growth from an initially high level (for instance, from 9 to 7 percent, or from 8 to 6 percent) may still allow a country to maintain rapid convergence to a high-income status. The slowdown may thus be a temporary phenomenon, related for instance to the existence of increasing returns in the education sector caused by human capital externalities, and the fact that individuals choose to spend more time studying and improving their skills (see Kejak (2003)). Third, if the middle-income trap were to be defined relative to a leading country (or a group of leading countries), a more relevant metric would be the country's growth rate vis-à-vis that country (or group of countries). This is particularly important in view of the evidence provided by Aiyar et al. (2013), which suggests that TFP slowdowns in middle-income countries tend to be more frequent than in low- and high-income countries. At the same time, however, a growth "slowdown" may be no more than a temporary phenomenon, which may lengthen the transition time to high-income status, but it is not necessarily synonym with being "trapped" in a low-growth state.

Felipe et al. (2012) followed an altogether different approach. They begin their analysis by defining four income groups of absolute levels of GDP per capita during the period 1950-2010: low income (below $\$ 2,000$ ), lower middle-income (between $\$ 2,000$ and $\$ 7,250$ ) upper middle-income (between $\$ 7,250$ and $\$ 11,750$ ), and high income (above $\$ 11,750)$. They argue that if a country is stuck in the lower middle-income category for more than 28 years, or in the upper-middle income for more than 14 years, then the country is caught in a middle-income trap. These thresholds represent the median number of years that the sample countries spent in their income categories. Thus, avoiding the middle-income trap is a question of how to grow fast enough in order to cross the lower middle-income segment in at most 28 years, and the upper middleincome segment in at most 14 years. Based on these numbers, they found that, out of 124 countries in their sample, there were 52 middle-income countries in 2010; and out of that group, 35 countries (of which 13 in Latin America, 11 in the Middle East 
and North Africa, and 3 in Asia) were caught in a middle-income trap. Moreover, using disaggregate trade data, they found that countries caught in that trap were all characterized by lower sophistication and diversification of their exports.

There are two major limitations to this study, both of them related to the thresholds that they set. First, taking the median of a limited set of countries is a somewhat arbitrary approach. For instance, if the authors had taken the mean instead of the median, the threshold for the lower middle income would have been 33 years instead of 28 years. Second, the sample has only a limited number of countries making the transition from one income level into another. The thresholds (which are kept constant in real terms over time) could differ therefore significantly for other sets of countries. ${ }^{6}$ Nevertheless, the evidence that suggests that improved diversification and sophistication of production and exports - which itself points to the key roles of human capital, structural change and innovation as the main drivers of total factor productivity growth - are important; it is consistent with the key message of the descriptive studies referred to earlier and is further discussed next.

A broader criticism of the econometric evidence, echoing an important contribution by Quah (1993) in the context of the convergence debate, was put forward by Pritchett and Summers (2014). If changes in growth rates are randomly but identically distributed across countries, then there would be, by virtue of Galton's regression to the mean, a correlation between higher growth rates and lower subsequent income. This is because those countries that had experienced high (low) growth in the past would inevitably tend to grow slower (faster) in the future. However, for the concept of regression to the mean to be valid, the premise must indeed be that growth outcomes are random. This assumption is not consistent with the statistical regularities that the literature on growth empirics has uncovered with respect to the role of geography,

\footnotetext{
${ }^{6}$ In a subsequent study, Felipe et al. (2014) extend their data to 2013, revise the income classification of economies to smooth out fluctuations in the various income categories that they define, and revise the criteria used in their earlier paper to determine whether an economy is trapped or not. A key finding of their paper is that over a longer period of time, the relatively fast transitions to high-income status observed since 1950 (especially in East Asia) do not appear to be the norm. In fact, The median number of years spent in the lower middle-income group is now estimated at 55 years, rather than 28 years. But because the methodology used remains the same, the limitations of their previous contribution continnue to hold.
} 
institutions, openness to trade, and so on (see Agénor (2004) and Acemoglu (2009)). There is also no clear rationale for assuming a priori that growth rates are identically distributed across countries facing vastly different economic conditions. In fact, it is possible that many countries may have a stochastic growth path, which may be reflect bad luck, bad policies, or a combination of the two (see Ye and Robertson (2015)).

A fair assessment would nevertheless recognize that, in addition to difficulties in identifying slowdowns, the econometric literature on middle-income traps remains vulnerable to a range of problems that have plagued cross-country growth regressionsincluding sample selection bias, measurement and specification errors, inadequate tests for pooling, and simultaneity bias (see Agénor (2004) and Acemoglu (2009)). There is also significant room to improve, as will become clear later, the identification of nonlinearities associated with interactions between causes of middle-income traps. The crucial point, however, is that even though the identification of precise turning points and other empirical regularities (such as the magnitude of growth slowdowns when they do occur) using cross-country data remains a matter for debate, and that these slowdowns may in fact occur with the same (if not higher) frequency in other income groups as well, this does not invalidate the fact that the concept of a middle-income trap is useful to understand the experience of individual countries and the policy challenges that productivity slowdowns, and the transition to high-income status, present to them. A sensible approach from that perspective, and one that will be followed in the remainder of this paper, is to attempt to identify some of the key structural features that are consistent with the various causes of middle-income traps.

\section{Causes of Middle-Income Traps}

Various explanations have been put forward to explain the existence of middle-income traps. In line with the descriptive and statistical evidence discussed earlier, these explanations include diminishing returns to physical capital, exhaustion of cheap labor and imitation gains, insufficient quality of human capital, inadequate contract enforcement and intellectual property protection, distorted incentives and misallocation of talent, lack of access to advanced infrastructure, and lack of access to finance. Before they 
are considered in more detail, it is important to note that many of these arguments are fundamentally consistent with the evidence that views productivity slowdowns as the main source of middle-income traps; they differ from each other mainly in terms of the reasons why these slowdowns occur-and, by implication, what type of public policies can be implemented to promote productivity growth. As such, they may well be complementary in nature rather than substitutes.

It is also useful to make, at the outset, an analytical distinction between middleincome traps and the more common notion (at least among economists) of poverty traps. In general, a poverty trap is defined as a self-reinforcing mechanism that causes poverty to persist, that is, a "locked-in" equilibrium associated with stagnation (zero growth) or very low growth in income over time. A typical poverty trap is often due to a lack or limited availability of a key production input or public good - insufficient supply of private capital due to low savings and low income to begin with, coordination failures, inadequate public infrastructure, insufficiently developed credit and capital markets, poor access to public health or education services, weak institutions, and so on - in an environment where income per capita is initially low. ${ }^{7}$ By contrast, a middle-income trap typically occurs after a country has been growing rapidly for a sustained period of time and has improved substantially the standards of living of its population- so that the question is more about explaining a slowdown in growth, rather than why it is low in the first place - and for reasons that are not generally related to those that explain why a poor country may be stuck in a bad, path-dependent equilibrium. It is often not the quantity of production inputs (public or private) that matters, but rather their quality. For instance, access to electricity may be available to most in urban areas, but it can be highly unreliable; roads may cover most of the country but they are of poor quality; human capital (in terms of tertiary education) may be high on paper, but the quality of training is poor; and so on. Indeed, the fundamental source of multiple equilibria in a middle-income trap is often related to the lack of innovation

\footnotetext{
${ }^{7}$ Poverty traps can occur in models with either a single (stagnation) equilibrium or multiple equilibria. See Iwaisako (2002), Azariadis (2006), Azariadis and Stachurski (2005), Kuwahara (2007, 2013), Guillaumont (2009), Agénor and Aizenman (2010), Bénassy and Brezis (2013)), Wang and Wang (2013), Agénor (2015), and Ghatak (2015) for recent contributions to, and discussion of, the literature on poverty traps.
} 
activity - itself related to poor quality of human capital, which may prevent a country from escaping a low- or moderate-growth equilibrium - rather than, say, low savings, poor nutrition, lack of basic infrastructure, etc., as typically observed in low-income countries. However, as discussed later, the main insights that the theory of poverty traps provides are important to understand the role of public policy in helping to escape from a middle-income trap.

\subsection{Diminishing Returns to Physical Capital}

A first argument to explain a middle-income trap (particularly with respect to the experiences in East Asia, and the Middle-East and North Africa) relates to diminishing marginal returns to physical capital. In the initial stages of economic development, high rates of investment (especially by the public sector) generate strong benefits in terms of economic growth - in the case of public investment either directly through its impact on the productivity of private inputs or indirectly by fostering private investment through a complementarity effect (see Agénor (2012)). Sustained rates of capital accumulation have indeed been a key feature of the experience of East Asian countries in the aftermath of the Second World War (see for instance Commission on Growth and Development (2008) and Lee and Hong (2010)). But as economies develop, capital accumulation (both private and public) becomes subject to diminishing marginal effects. The growth benefits of that strategy - which occur during a stage of extensive growth, as characterized by Kejak (2003) - therefore get eroded over time. Unless other policies are adopted to promote economic growth, a country may be unable to continue its transition from middle-income to high-income stage.

A related but different argument is that, over time, the efficiency of investment (especially public) gets eroded; because of corruption or mismanagement, a smaller fraction of (investment) flows turn into (capital) stocks. At the same time, due to the same factors the quality of (public) capital may weaken, thereby diminishing its marginal benefits for the economy. Thus, the issue is not that the marginal return to capital falls because there is too much of it - if anything, less efficient investment means lower stocks - but rather that its quality deteriorates, and that in turn eventually has an adverse effect on growth. If empirical measures of capital stocks do not 
capture this deterioration, they may overestimate the growth in the capital stock and its contribution in growth accounting exercises.

The cross-country econometric literature points out that the growth slowdowns that are associated with a middle-income trap are essentially productivity slowdowns rather than simply the consequence of decreasing returns in physical capital accumulation. For instance, in the study by Eichengreen et al. (2012) discussed earlier, 86 percent of the growth slowdown is estimated to result from a slackening in TFP growth, compared to only 15 percent to capital accumulation. In the same vein, Daude (2010) found that TFP plays a key role in explaining the persistent per capita income gap between Latin America - a region where, as noted earlier, a number of countries appear to have fallen in a middle-income trap - and the United States, in contrast to differences in factor accumulation. In addition, there does not appear to be any systematic cross-country evidence to suggest that investment efficiency tends to deteriorate significantly when countries reach middle-income status.

Nevertheless, the fact that the cross-country evidence does not provide much support for either diminishing marginal returns to capital or a deterioration in investment efficiency does not mean that these hypotheses do not hold any explanatory power at the level of some individual countries. A case in point is Morocco, where for the past three decades growth has been fueled by high rates of public investment (see Agénor and El Aynaoui (2015)). While these investment rates - some of the highest in the world, even by Asian standards - had undeniably a positive effect on production capacity and output, the evidence shows that over time public capital accumulation also suffered from efficiency problems and diminishing returns: in particular, the incremental capital-output ratio (ICOR) increased from an average of less than 3 in the 1990s to an average of 8.1 during the past decade. By contrast, in China for instance, a country where government investment is widely seen as highly inefficient, ICOR rose from 3.8 to only 4.6 between 1983 and 2010 (Lee et al. (2012)). Thus, the diminishing returns to capital hypothesis may be useful to understand why some countries may transition to a slower growth path before catching up with richer countries. 


\subsection{Exhaustion of Cheap Labor and Imitation Gains}

Another explanation of growth slowdowns is based on a Lewis-type development process. In that perspective, factors and advantages that generate high growth during an initial phase of rapid development - low-cost labor and imitation of foreign technologydisappear when middle- and upper-middle-income levels are reached, thereby requiring new sources of growth to maintain sustained increases in per capita income.

Indeed, during an initial phase, low-income countries can compete in international markets by producing labor-intensive, low-cost products using technologies imported from abroad. These countries can achieve large productivity gains at first through a reallocation of labor from low-productivity agriculture to higher-productivity manufacturing. Because producers of nontraded goods must compete with exporters for labor, they need to pay attractive wages. At the same time the chance of well-paid work in manufacturing creates an incentive for workers to move to cities and invest in education. However, once these countries reach middle-income levels, the pool of underemployed rural workers shrinks and wages begin to rise, thereby eroding competitiveness. Productivity growth from sectoral reallocation and technology catch-up are eventually exhausted, while rising wages make labor-intensive exports less competitive on world markets - precisely at the time when other low-income countries initiate a phase of rapid growth. Put differently, persistent growth slowdowns coincide with the point in the growth process where it is no longer possible to boost productivity by shifting additional workers from agriculture to industry and where the gains from importing foreign technology diminish. This process is well supported by the evidence on productivity slowdowns provided by Eichengreen et al. (2012), as indicated earlier; it is also relevant for understanding the recent slowdown in China. ${ }^{8}$ More generally, as documented by Dabla-Norris et al. (2013), the reallocation of labor from low-productivity agriculture to high-productivity sectors (initially manufacturing and subsequently services) was a primary channel through which today's advanced economies increased

\footnotetext{
${ }^{8}$ In China, the industrialization-through-imitation and cheap labor costs process started in 1979, when the country's leader then, Deng Xiaoping, chose the village of Shenzhen as the first special economic zone. Wages and productivity in urban factories were still substantially higher than in rural areas, creating a massive flow of workers from the countryside.
} 
their living standards. ${ }^{9}$

This process is also consistent with the analysis in Perez-Sebastian (2007), Glass (2010), Agénor and Dinh (2012), and Agénor and Alpaslan (2014), where imitation, due to large externalities associated with technology diffusion, is the main source of productivity growth in the early stages of development, whereas broad-based innovationdefined as the application of new ideas, technologies, or processes to productive activitiesbecomes the main engine of growth as the economy approaches the world technology frontier. While imitation is intensive in low-skilled labor, innovation requires only skilled labor, as for instance in Vandenbussche et al. (2006). Both imitation and innovation are costly, but the former is cheaper. By specializing initially in low-skilled intensive activities, a low-income country may be unable to provide sufficient incentives to workers to invest in education - hence reducing the rate of accumulation of human capital needed to promote at a later stage broad-based innovation. Thus, as much as a developing economy can use an imitation-based strategy to escape from a low-income poverty trap, the same strategy often becomes the major impediment that holds back the economy from switching successfully to innovation-driven growth.

The foregoing discussion also suggests that countries that are caught in a middleincome trap are often characterized by production structures that have changed little over time and have been unable to adapt to major structural changes in global trade, especially the vertical and spatial fragmentation of manufacturing into highly integrated global production networks (see Park et al. (2013)). As a result, exports of these countries are also characterized by a high degree of concentration in low-sophistication goods, as documented for instance by Felipe et al. (2012).

\subsection{Insufficient Quality of Human Capital}

Another factor that may explain a middle-income trap is poor quality of human capital. As noted earlier, tertiary education rates may be relatively high and increasing over time, yet the productivity of workers may remain relatively low and their skills insufficiently diversified. Poor quality of human capital acts as a constraint on the

\footnotetext{
${ }^{9}$ Put differently, transitioning from middle- to high-income level is typically accompanied by a major industrial transformation, an issue that is further discussed later on.
} 
ability to absorb more advanced foreign technologies and on the expansion of innovation activities, thereby preventing the productivity growth that may allow a country to sustain high levels of economic growth. ${ }^{10}$ Stone and Shepherd (2011) for instance found that the availability of skilled labor is a particularly important determinant of a firm's ability to generate productivity gains from intermediate and capital goods imports, that is, to realize dynamic gains from trade.

A useful framework to understand these issues is the one developed by Redding (1996), in which deficiencies in training and education can constrain firms' investments in product quality. In the model, workers invest in the acquisition of skills, whereas firms invest in quality-augmenting R\&D. The two forms of investment exhibit pecuniary externalities (through changes in wages) and are strategic complements. The incentives for both forms of investment are interdependent: individuals' returns from investing in human capital (the expected wage) depends on whether they expect firms to invest in $R \& D$, whereas firms' decisions to invest in $R \& D$ depends on their expectation of workers' investment in human capital, which affects the expected return to R\&D. Both types of investment determine the economy's growth rate and, in the presence of fixed costs associated with research, multiple equilibria may exist. The lowgrowth equilibrium, characterized by no investment in $\mathrm{R} \& \mathrm{D}$ and growth driven only by (low investments in) human capital, can be interpreted in the present context as a middle-income trap, with stagnant technology and no product quality improvements. To escape from the trap (which entails a discrete jump to the high growth equilibrium), policies that contribute, in particular, to reducing fixed costs (possibly through public subsidies, assuming that they are not financed by distortionary taxes), increasing the probability of innovation, or improve the quality of time spent in education, are necessary.

Redding's model is fairly simple; in particular, it does not explicitly account for the skills distribution or physical capital accumulation, and production exhibits constant returns to human capital. Thus, as in Lucas-type models, it is the growth rate of human

\footnotetext{
${ }^{10}$ Conversely, the data for Korea, compared to other Asian countries, suggest a clear correlation between the quality of the labor force, the proportion of researchers in the economy, R\&D expenditure, and growth in per capita income; see UNESCO (2014, Tables 12 and 13).
} 
capital that sustains steady-state growth in output. However, similar results could be established in more general settings, such as Agénor and Dinh (2012), in which there is also interdependence (through wage incentive effects) between human capital decisions and the development of innovation activities. In that model, private capital exhibits constant marginal returns (as in typical $A K$ models) and it is the level of human capital, that is, the proportion of skilled workers in the working age population, that affects the growth rate. Nevertheless, by adding fixed costs to innovation, results similar to those discussed by Redding could also be derived.

The theory of leapfrogging — or lack thereof - developed by Acemoglu et al. (2006) could provide an alternative conceptual basis for middle-income traps. In their framework, the selection of high-skill managers and firms is more important to promote innovation than for the adoption (or imitation) of foreign technologies. While in early stages of development selection matters relatively little, it becomes crucial as countries get closer to the world technology frontier and competition against foreign producers intensifies. The reason is that the rent-shielding effects that the low-skill managers benefit from as insiders protect them from potentially more efficient newcomers, and this is socially costly in the long run. The failure to improve the selection of managers and the organization of production processes may constrain the ability to adopt frontier technologies, dampen productivity gains, and prevent full convergence to that frontier. This non-convergence trap is similar, in spirit at least, to a middle-income trap caused by poor quality of human capital. ${ }^{11}$ ??

The inability to improve the quality of the labor force as countries get closer to the world technology frontier is an important factor in understanding not only the emergence but also the persistence of middle-income traps, especially in Latin America. Indeed, it is consistent with the evidence on measures of cognitive skills for that region reported in Hanushek and Woessmann (2012a, 2012b). Brazil is a case in point (see OECD (2014)). Even though the average number of years of schooling increased dramatically between 1990 and 2010, PISA scores in mathematics, reading, and science, put the country's rankings at 58, 55, and 59, respectively, out of 65 countries,

\footnotetext{
${ }^{11}$ Yet another alternative theory of nonconvergence traps could be based on the model of "catching up" and "falling back" with endogenous worker productivity developed by Benhabib et al. (2014).
} 
in 2012. Poor quality of human capital is also one of the key issues for Malaysia (see Hill et al. (2012) and Flaaen et al. (2014)). Indeed, although a net labor importer, Malaysia remains a net skills exporter, with growing numbers of professionals migrating to Singapore and other industrialized countries. Partly as a result of this brain drain, workers in Malaysian manufacturing remain largely low skilled, with more than 80 percent holding only a high school degree, and just 7 percent of manufacturing employees holding a university degree (Menon and Woo (2014)). The country's PISA scores are not much better than Brazil's, even though education attainment, measured in terms of average years of schooling, was close to the OECD average in 2010 (see OECD (2014, Tables 2.1 and 2.8)). Even though education attainment was not as high in Thailand, a similar contrast between years of schooling and PISA scores scenario can also be observed for that country.

\subsection{Distorted Incentives and Misallocation of Talent}

Related to the previous argument is the possibility that pecuniary externalities may translate into a misallocation of talent; individuals with potential ability to be highly productive in innovation activities end up working in sectors that are less beneficial in terms of growth, because wages there are higher or less uncertain. The issue therefore is the (sectoral) distribution of human capital, rather than the accumulation of human capital per se.

This issue is addressed formally by Agénor and Canuto (2015), in an overlapping generations (OLG) model with endogenous occupational choices. ${ }^{12}$ They distinguish between two types of labor skills, basic and advanced, with the latter defined as specialized knowledge that can be acquired by devoting a given amount of time to higher education in early adulthood. Thus, in contrast to models with disembodied knowledge and endogenous schooling time allocation, in the Lucas-Uzawa tradition, human capital cannot be accumulated indefinitely. Individuals with either basic or advanced skills can both work in the production of final goods, whereas only those with advanced skills

\footnotetext{
${ }^{12}$ Actually, Agénor and Canuto consider jointly the issue of insufficient access to (advanced) infrastructure and misallocation of talent. For pedagogical reasons these issues are discussed separately here. A simplified version of the Agénor-Canuto model is presented in the more detailed version of this article, available upon request.
} 
can work in the innovation sector. Occupational choices are endogenous; individuals choose to invest in education only if wages in the innovation sector are high enough, compared to other sectors. In addition, unlike existing models, where the marginal productivity gain associated with the stock of ideas is either constant or decreasing, this gain is assumed to be increasing over a certain range due to learning-by-doing effects.

Their analysis shows that, depending on initial conditions, a middle-income growth trap, characterized by a relatively low initial share of high-ability workers engaged in the innovation sector, may emerge in equilibrium. Moreover, the trap may be characterized by a misallocation of talent, due fundamentally to the fact that the wage in the design sector is ex ante too low relative to the going wage in manufacturing.

More generally, it is worth noting that the misallocation of talent may also result from poor contract enforcement and protection of intellectual property rights, and the inadequate provision of incentives to engage in risky entrepreneurial activities or, as discussed later, from constraints in accessing finance. The key reason is that innovation is an inherently risky activity; the returns to investment can be highly uncertain. So unless appropriate measures are taken to encourage individuals to engage in these activities, and to ensure that they can enjoy the rewards of their discoveries, even those with high potential and some appetite for risk may (rationally) choose to get safer jobs - a decision that may be socially very costly.

\subsection{Lack of Access to Advanced Infrastructure}

Modern day infrastructure can be classified into two types: basic infrastructure (which consists of roads, electricity, and basic telecommunications) and advanced infrastructure, which consists of advanced information and communication technologies (ICTs) in general, and high-speed communication networks in particular. It is now well established that access to broadband facilitates the buildup of domestic and international knowledge networks, thereby promoting dissemination and research as well as innovation and growth (see Canuto et al. (2010) and Czernich et al. (2011)). Broadband networks also provide a platform that other sectors can leverage to develop other platforms (such as distance education and telemedicine) and enable the development of 
digital content - all of which can help to increase productivity.

Agénor and Canuto (2015) have emphasized, in the model with heterogenous abilities described earlier, the lack of access to advanced infrastructure as a cause of a middle-income trap. To highlight the benefit of ICTs, they assume that advanced infrastructure serves to promote activity only in the design sector. ${ }^{13}$ Because labor supply decisions are endogenously related to relative wages, there is therefore a twoway interaction between these activities and the proportion of the population acquiring advanced skills. The key result that they establish is that, in line with the foregoing discussion, if the marginal benefits associated with nonrival knowledge depends in a nonlinear fashion on the share of the population involved in design activities, as a result of knowledge network externalities then multiple equilibria may emerge - one of them (the lower-growth equilibrium) being synonymous with a middle-income trap. Intuitively, to create ideas and benefit the most from existing knowledge, there must be enough high-ability individuals involved in the design sector; but if productivity in that sector is low, because access to advanced infrastructure is limited, wages will be relatively low-implying that few high-ability individuals will choose to invest, to begin with, in the advanced skills needed to operate in that sector. Thus, lack of access to advanced infrastructure, through its effect on relative wages and the acquisition of skills, may also contribute to a misallocation of talent.

\subsection{Lack of Access to Finance}

There is growing evidence that access to finance represents a major constraint on innovation and growth in developed and developing countries alike. ${ }^{14}$ A key reason for that is the inherent difficulty for firms engaged in innovation to resort to external finance.

\footnotetext{
${ }^{13}$ This assumption helps to simplify matters but it is not crucial; what matters is that advanced infrastructure be relatively more productive in innovation activities, compared to the production of goods.

${ }^{14}$ See Ayyagari et al. (2011), Brown et al. (2012), and Hottenrott and Peters (2012). As pointed out by the Inter-American Development Bank (2010), lack of finance - in addition to a shortage of highly qualified personnel (alluded to earlier) and small domestic markets - is one of the key obstacles to innovation in Latin America. At the same time, it can be argued that although a country like Korea has succeeded - mainly because the R\&D activities of its largest and most competitive conglomerates were financed internally or through captive funds - in becoming an innovation-based economy without highly developed venture capital markets, it could have performed even better if its small and mediumsize innovative firms had not faced financial constraints.
} 
Assets held by these firms are mainly intangible; as a result, they may lack collateral value. Spending in the form of salaries and wages for scientists and researchers, which often represent a large fraction of innovation-related activities and help to build human capital, cannot be collateralized. Furthermore, to protect their proprietary information over innovation, firms may be unwilling to offer fully transparent signals about the effectiveness of their intended innovation programs to potential lenders. Limited collateral value and information frictions may thus help to explain why some of these firms - especially the smaller ones - rely little on debt finance and instead fund most of their investments with their own resources or (at later stages and where available) equity. Indeed, the high degree of information asymmetry that characterizes investment in innovation projects may induce lenders to demand higher rates of return than in the case of investments in physical assets. Thus, although information asymmetries may matter for external financing of all types of investments, they may be particularly significant for innovation activity due to its specificity. ${ }^{15}$ If financing constraints are binding for a sufficient number of innovative firms, economic growth may be adversely affected.

An analysis of how interactions between access (or lack thereof) to finance, product innovation, and labor supply can generate a middle-income trap is presented in Agénor and Canuto (2014). Their analysis shows that if research activity involves borrowing from financial intermediaries and monitoring is costly, high intermediation costs may adversely affect innovation. This is in line with some other contributions in the literature, including Aghion et al. (2005). In addition, if monitoring costs are high, fewer individuals may choose to invest in skills and engage in design activities. The reason is that high monitoring costs lead to lower wages in the design sector, which in turn lead (for a given cost of education) to reduced incentives to invest in skills and thus a lower share of the labor force engaged in research. From that perspective, lack of access to finance not only has a direct, adverse effect on innovation activity and growth, but also an indirect effect that operates in the same direction.

\footnotetext{
${ }^{15}$ Moreover, funding through equity is either costly - especially for firms whose values are determined mainly by their growth potential and hence are severely exposed to asymmetric information frictionsor simply not available, as is often the case for younger and smaller firms.
} 
They also show that if unit monitoring costs (as a result of positive information externalities, for instance) fall with the number of successful projects, multiple equilibria may emerge - one of which, a middle-income trap, characterized by low wages in the design sector, a low share of the labor force engaged in innovation activity, and low growth. A sufficiently ambitious policy aimed at alleviating financial constraintsthrough the development of capital markets rather than government subsidies, which may be difficult to target effectively - may allow a country to move away from such a trap, not only by reducing the cost of finance but also by improving incentives to invest in skills and promoting the production of ideas. ${ }^{16}$

This analysis also has implications for the debate on the optimal size of the financial sector. Indeed, there is growing evidence on the existence of "too much finance," as documented by Law and Singh (2014), Cecchetti and Kharroubi (2015), Sahay et al. (2015), and Samargandi et al. (2015). Yet, these contributions may have missed an important point; indeed, what the recent literature on the role of finance in causing middle-income traps suggests is that there is also a paradox: there can be at the same time "too much finance", but not enough of the "right finance," that is, the type of finance that may promote risky activities in innovation.

\subsection{Income Inequality}

Another possible cause of a middle-income trap is changing income inequality over time. The well-known Kuznets Curve suggests that greater income inequality is a price to pay for rapid growth in the early stages of economic development. ${ }^{17}$ As lowincome countries develop, with production shifting from agriculture to industry, income gaps between the top and the bottom income groups tend to increase. After reaching a middle-income stage, mass education and continued industrialization combine to foster

\footnotetext{
${ }^{16}$ It is worth noting that this analysis also has some relevance for slow-growing industrial countries. Indeed, there is compelling empirical evidence to suggest that in many of these countries access to finance remains an equally important constraint on the innovation activity of small and medium-sized firms. Inadequate access to finance may therefore be the source of a slow-growth equilibrium. In such conditions, a forceful policy aimed at promoting access to finance is also essential to escape from a low-growth equilibrium and put the economy on a path that would allow it to converge to a high-growth, high-innovation equilibrium.

${ }^{17}$ See for instance Grimalda and Vivarelli (2010) for a recent model of growth of the Kuznets-Lewis type.
} 
reductions in income inequality. However, persistence in inequality during the middleincome stage may act as a constraining factor on growth; a key reason for that is that it may prevent individuals (and their children) with low assets from acquiring skills, due to their inability to raise collateral and secure loans to finance advanced education. ${ }^{18}$ Egawa (2013) for instance offers a similar line of reasoning to explain why a middleincome country cannot continue to grow at sustained rates if income inequality remains high or worsens at that stage of development.

Some observers had indeed argued that countries like China, Malaysia, and Thailand are suffering from inequality in income distribution that may hinder their prospects for sustained economic growth. It has also been argued that one reason why Brazil (which had a growth rate comparable to South Korea until the 1980s, as noted earlier) was unable to transition into an innovation-based economy is a high degree of income inequality. However, between 2001 and 2009 income inequality fell significantly in that country. During that time, the income growth rate of the poorest decile of the population was 7 percent per year, while that of the richest decile was 1.7 percent; as a result, income inequality (as measured by the Gini index) fell markedly, from 0.594 in 2001 to 0.521 in 2011, that is, a fifty-year low. ${ }^{19}$ Thus, it is hard to argue that income inequality has been a major factor in explaining the country's persistent growth slowdown. More generally, there appears to be no formal evidence to suggest that greater inequality is associated with a sustained drop or stagnation in productivity.

\section{Escaping from Middle-Income Traps}

The perspective adopted in the foregoing analysis is that a middle-income trap is best understood not as a transitional state (the economy's position at a specific moment in time) but rather as an equilibrium state, which tends to be self perpetuating. The issue then is not only what causes growth to slow down, but also what to do (from a

\footnotetext{
${ }^{18}$ Cingano (2014) argued that this channel is the main factor explaining the negative correlation between inequality and growth observed in recent years in OECD countries.

${ }^{19}$ Key drivers of these achievements have been low inflation, sustained economic growth (at a yearly average of 4.0 percent during 2002-08 and 5.1 percent during 2010-11), well-focused social programs, and real increases in the statutory minimum wage. See Cornia (2012) and Lustig et al. (2012) for a more detailed discussion of what accounts for the reduction in inequality in Brazil during the past two decades.
} 
policy standpoint) when the slowdown has occurred and the economy has settled to a stable equilibrium in a context where multiple equilibria exist.

In such conditions, just like what the theory of poverty traps predicts, moving away from that equilibrium - as in any model with stable, multiple equilibria - requires a major change, namely a policy that is bold enough to shift the economy from the initial, low-growth equilibrium to a path that can lead it to a high growth equilibrium. Small changes in policies can only induce temporary deviations away from the initial equilibrium and the economy will eventually return to it. Yet, if a middle-income trap is viewed as a "bad" equilibrium in a setting where multiple equilibria exist, then temporary, properly targeted interventions can also have permanent consequences. And because what drives a country into a trap when it reaches middle-income status may often be a combination of factors (poor quality of human capital interacting with lack of finance, for instance), a critical mass of well targeted reforms may often be indispensable to set the economy in motion toward a high-growth path.

This section considers various public policies that can help a country avoid falling into, or escape from, a middle-income trap. To a significant extent, these policies are directly related to, or motivated by, the causal factors highlighted in the preceding section. Thus, policies or reforms that may be desirable in general from a growth standpoint (such as product market reform, as emphasized by OECD (2014)) are not discussed, because they are not fundamental from the perspective of avoiding, or escaping from, a middle-income trap.

\subsection{Raising the Quality of Education}

As noted earlier, the quality of education may be a key constraint that prevents a country from transitioning to higher-income status. More generally, increasing knowledge absorption capacity, namely, the ability to adopt and capitalize on ideas from more advanced economies and technology transfers (not only through international trade but also through foreign direct investment, as documented by the World Bank (2008) for instance) is key to promote innovation. From that perspective, targeted microeconomic reforms of the education system (such as increases in teacher-student ratios, better incentives for teachers, improved access to the internet in schools, and so 
on), rather than higher public spending on education per se, may be critical. In some countries, stopping the brain drain, and favoring "brain circulation" (capitalizing on the diaspora by promoting knowledge-sharing networks) may also be important.

Improving the quality of education is, indeed, one of the key policy prescriptions to accelerate the transition to high-income status in the coming two decades in Asia (Lee and Francisco (2012)) and Latin America (Inter-American Development Bank (2010)). At the same time, it must be recognized that high quality scientific knowledge and technical skills, while necessary, are not sufficient for the emergence of an innovation-based economy. The degree of diversification of competencies and skills is also important.

\subsection{Subsidies to Innovation}

Traditionally, government subsidies to R\&D are justified in terms of a divergence between private and social marginal returns (see OECD (2010)). From the perspective of escaping a middle-income trap, the justification is slightly different - it is mainly in terms of equilibrium selection. To the extent that they help to prop up wages in the innovation sector and reduce the inherent degree of uncertainty associated with the returns to innovation, temporary public subsidies can also help to mitigate the misallocation of talent alluded to earlier. However, subsidies to innovation are unlikely to work if the binding constraint on productivity growth in the innovation sector is related to another factor, such as the lack of access to advanced infrastructure. In that case, correcting distortions in terms of incentives to work in innovation activities requires a combination of policies.

\subsection{Contract Enforcement and Protection of Property Rights}

Poor contract enforcement and lack of protection of property rights (especially intellectual rights) are key weaknesses in developing countries in general, and middle-income countries in particular. According to the OECD (2014, p. 176) for instance, countries like Brazil and Morocco fare poorly compared to industrial countries in terms of a "contract enforcement score" and an intellectual property index. These weaknesses tend to weaken confidence and may have an adverse effect on all aspects of economy activity; but they may be particularly detrimental to innovation activities. Indeed, the 
inability to sanction in the event of a contract being breached, and especially inadequate intellectual property protection, may act as major constraints on the incentives to engage in innovation because the return to that activity is not certain and because (as noted earlier) firms may be unwilling to offer fully transparent signals about the effectiveness of their intended innovation programs to potential lenders. As a result, this may make it more difficult to secure access to finance.

Contract enforcement requires that a legal system incorporates effective mechanisms of law enforcement, namely, an impartial judicial system, whereas securing intellectual property rights requires not only to develop new legislation but also to raise awareness of existing laws. However, very few countries that have been thought to be in a middleincome trap (in Latin America and elsewhere) have managed to make improvements in that regard.

\subsection{Promoting Advanced Infrastructure}

As noted earlier, lack of access to advanced infrastructure may be an important barrier to the development of national and international knowledge networks and the increase of productivity. As discussed earlier, if the marginal benefits associated with nonrival (disembodied) knowledge depends in a nonlinear fashion on the share of the population involved in design activities (being high for a range of values for that share), as a result of the knowledge network externality alluded to earlier, then a middle-income trap, characterized by low productivity growth may emerge. Intuitively, to create ideas and build on existing knowledge, there must be enough "high IQ" individuals involved in $\mathrm{R} \& \mathrm{D}$; but if productivity in that sector is low, because access to advanced infrastructure is limited, wages will also be low-implying that few people will choose to invest in the advanced skills needed to operate in that sector. Escaping from the trap may be achieved by a sufficiently large increase in investment in advanced infrastructure. ${ }^{20}$ The

\footnotetext{
${ }^{20}$ Because of nonlinearities associated with the benefits of advanced infrastructure (as is the case for broadband networks documented by $\mathrm{Cz}$ (2011), for instance, the critical mass of reforms advocated here may well involve a Big Push in that category of investments. However, this does not have to come from an overall increase in public spending, it could very well come from a reallocation of investment, away from spending on basic infrastructure. This is indeed an important consideration for countries like China and Morocco where, as discussed earlier, the efficiency of public investment may have fallen significantly in recent years.
} 
key reason is that improving access to this type of infrastructure boosts productivity and wages in the design sector, which draws more labor there and may trigger the shift in labor supply that magnifies (at least temporarily) the benefits associated with exploiting ideas and absorbing new technologies.

Because of the lumpy nature of infrastructure investments in general, and the nonlinearities associated with the benefits of advanced infrastructure in particular (as is the case for broadband networks documented by Czernich et al. (2011), for instance), the increase in spending in that category of investments may well need to be substantial. However, it does not have to come from an overall increase in public spending, as a Big Push theory would advocate. It could instead come from a reallocation of public investment, away from spending on basic infrastructure, and improved management of investment projects. These are indeed important considerations for countries like China and Morocco where, as discussed earlier, the efficiency of public investment (much of it still devoted to basic infrastructure) may have fallen significantly in recent years. Moreover, advanced infrastructure does not need to be provided by the public sector only; given the costs involved and tight budget constraints in many countries, partnerships between the state and the private sector could provide viable alternative options. ${ }^{21}$

\subsection{Improving Access to Finance}

As noted earlier, information asymmetries are likely to be especially binding on talented individuals and small enterprises that lack collateral, credit histories, and connections, and limit their ability to secure external funds for the financing of innovation projects. The foregoing discussion, based on Agénor and Canuto (2014), suggested that access (or lack thereof) to finance may constrain growth not only by increasing the cost of monitoring innovation activities, as emphasized in other contributions such as Aghion et al. (2005) and Aghion and Howitt (2009), but also by altering incentives to acquire skills. Indeed, the degree to which firms innovate and the distribution of skills among workers (which conditions the development of innovation activities) are jointly deter-

\footnotetext{
${ }^{21}$ See Engel et al. (2014) for a discussion of issues associated with public private partnerships in the provision of infrastructure.
} 
mined; lack of skills and poor access to finance are interrelated. ${ }^{22}$ These interactions can lead to a middle-income trap, characterized by a misallocation of talent and a high cost of financial intermediation. ${ }^{23}$

In this context, public policy aimed at mitigating the impact of these imperfections (or, more specifically, those aimed at reducing the unit cost of monitoring R\&D projects) may allow a country to avoid falling into, or to escape from, that trap. Ensuring access to more funding sources may lead to more intensive innovation, more successful R\&D projects which, in turn, may result in lower unit monitoring costs, thereby helping to further promote financial intermediation, innovation, and economic growth. ${ }^{24}$ However, rather than providing direct subsidies (given well-known targeting problems), an alternative policy would be to implement measures that are aimed directly at mitigating asymmetric information problems and reducing unit monitoring costs, such as for instance the creation of credit bureaus or registries that help to collect, analyze, and disseminate information about potential borrowers to lenders. The evidence suggests, for instance, that more effective credit information sharing is associated with greater availability and lower cost of bank loans to firms (World Bank (2014, Chapter 3)). Such a policy may actually be more effective in middle-income countries, given a weak institutional environment and the practical difficulties that may arise in selecting research projects whose outcomes are inherently uncertain.

Improved access to finance for innovative firms may also have side benefits - it may improve incentives to acquire skills, and therefore indirectly help to promote innovative research. At the same time, however, it is important to realize that in practice a strategy of promoting the financial sector across the board may not yield only benefits. The reason is that it could lead (as discussed earlier) to a misallocation of talent. Indeed, if the expansion of the financial sector, by offering higher earnings and rewards,

\footnotetext{
${ }^{22}$ Attitude toward risk matters as well; to turn a promising idea into a new firm, researchers must also face the right incentives to give up safe employment for a risky entrepreneurial career.

${ }^{23}$ These characteristics of the middle-income trap could equally apply to some high-income OCED countries where growth has remained anemic for significant periods of time, and promoting innovation remains a key policy challenge.

${ }^{24}$ The fact that in practice the importance of financial constraints may vary with firm characteristics points also to another conclusion: for any innovation policy program to be effective it is vital not to rely on uniform $\mathrm{R} \& \mathrm{D}$ and innovation support measures, but to provide programs that support different firms in different ways.
} 
draws too many talented individuals, it could hamper in the long run the development of the innovation sector. Thus, rather than promoting finance in general, what is needed is a well-targeted policy aimed at making it easier for innovative firms to secure adequate funding for their activity. Put differently, from the perspective of escaping a middle-income trap, the problem is not too much finance (the size of the financial sector) but the degree of diversification of finance.

In sum, the middle-income trap is not an unavoidable outcome. To steer clear from it and manage the transition to high-income status requires structural reforms to boost technological catch-up, facilitate structural transformation into higher productivity sectors and new activities, and better allocate existing resources in the economy.

\section{Concluding Remarks}

The purpose of this paper was to provide an overview of the recent analytical and empirical literature on middle-income traps. The first part of the paper reviewed the evidence on these traps and pointed out some of the limitations of existing crosscountry studies. It was argued that, despite these limitations, the concept of a middleincome trap is useful from a policy perspective because it calls attention to the limited number of middle-income countries that have been successful in attaining a developed economy status - even if absolute incomes have risen and non-income dimensions have improved substantially in many of them. In so doing, it helps to recognize the particular challenges that countries may face once they reach a particular stage of development.

In the second part of the paper the various arguments that have been put forward to explain the existence and persistence of middle-income traps were discussed. A key conclusion of the analysis is that a middle-income trap is often an imitation trap, that may result from interactions between the lack of advanced public capital or inadequate access to finance, and lack of high quality human capital involved in innovation activities. It was also argued that from an analytical perspective, rather than slow movement toward a unique equilibrium due to structural and policy differences across countries, as emphasized in the conventional literature on growth convergence, a middle-income trap is best viewed as a bad but stable equilibrium to which a country may gravitate 
as a result of different initial conditions.

The analysis then focused on policies aimed at escaping from, or avoiding, a middleincome trap. The key issue from that perspective is what type of policy reforms must be implemented to boost productivity growth and create incentives to engage in R\&D. The discussion emphasized the importance of raising the quality of human capital, investing in advanced infrastructure, improving contract enforcement and securing intellectual property rights, and improving access to the right type of finance to promote innovation. Complementarities between these policies means that reform programs must be sufficiently ambitious in terms of their breadth. Moreover, at the level of each policy threshold effects may exist; a reasonably high stock of high quality human capital may be needed before an economy can shift to an innovation-based growth process, access to advanced infrastructure must be sufficiently broad to allow knowledge networks to develop, and so on. The existence of these effects, combined with the fact that by their very nature middle-income traps are stable equilibria, means that targeted policy reforms must be sufficiently bold to allow an economy to shift toward higher valueadded, knowledge-intensive activities, promote product differentiation (increasing the variety and the characteristics of goods produced) and product upgrading (improving the quality of the existing goods), and eventually transition to higher income status.

The foregoing analysis also has important implications for the sequencing of growth strategies in low-income countries. For many of today's poor countries, imitation is an important initial phase; policy should focus first on strengthening the basic infrastructure necessary for the successful adoption, diffusion, and implementation of already existing technologies, and on developing basic domestic human capital. At the same time, if there are spillover effects on learning associated with imitation activities, they may also promote knowledge accumulation. This two-way causality implies that an initial phase of specialization in imitation activities is not necessarily detrimental to sustained growth in these countries. However, the risk for countries specializing in low-skilled intensive activities is that they entail rapidly diminishing returns. With inadequate incentives to invest in higher education, and insufficient investment in research-promoting infrastructure, their longer-term prospects may be constrained and they may fall into a low-growth imitation trap. It is therefore important to act in a timely fashion and 
begin early enough to step up investment in human capital and advanced infrastructure, to improve the country's capacity to compete at the global technological frontier and ensure sustained growth. Delays in making these investments may be costly, as some slow-growing middle-income countries have now found out. ${ }^{25}$

The existing literature can be expanded in several directions. At the theoretical level, further research is needed to understand how R\&D spillovers and income inequality can lead to a low-growth trap. ${ }^{26}$ A better understanding of the role of political economy factors is also needed; it is possible, for instance, that as countries become richer, the demand for democratic rights increases; this may exacerbate the common pool problem - because interest groups do not internalize the impact on the government budget of their competing demands for public resources - thereby leading to chronically high fiscal deficits and public debt, which deter private investment and stifle growth. Alternatively, "institutional reversals," associated with changes in the political environment may also explain growth slowdowns, as argued for instance by Acemoglu and Ucer (2015) in the case of Turkey.

Yet another fruitful direction would be to examine to what extent the recent literature on secular stagnation in an industrial-country context - such as the contribution of Eggertsson and Mehrotra (2014), which highlights in particular the role of increases in inequality and a fall in the relative price of investment as sources of persistence in output slumps - could provide additional insights, above and beyond those discusses here, to understand the growth slowdowns that may occur in a middle-income context. At the empirical level, better attempts to estimate how the various causes of poverty traps interact is essential to inform policy choices. It is also important to develop empirical tests based on more advanced nonlinear techniques, such as for instance the tests for threshold effects in the context of dynamic heterogeneous panel data models developed by Chudik et al. (2015) in a different context.

\footnotetext{
${ }^{25}$ The "unbundling" of manufacturing into global supply chains also has important implications for the type of growth strategy that today's low-income countries should pursue to avoir falling into a middle-income trap. See UNIDO (2009) and Rodrik (2015) for instance for a discussion.

${ }^{26}$ Chen and Chu (2010) for instance found that with R\&D spillovers across firms, strengthening patent protection may actually stifle innovation and deter growth. However, this result is based on a model that does not capture the benefits of intellectual property protection for risk taking.
} 


\section{References}

Acemoglu, Daron, Introduction to Modern Economic Growth, Princeton University Press (Princeton, New Jersey: 2009).

Acemoglu, Daron, Philippe Aghion, and Fabrizio Zilibotti, "Distance to Frontier, Selection, and Economic Growth," Journal of the European Economic Association, 4 (March 2006), 37-74.

Acemoglu, Daron, and Murat Ucer, "The Ups and Downs of Turkish Growth, 2002-2015: Political Dynamics, the European Union and the Institutional Slide," Working Paper No. 21608, National Bureau of Economic Research (October 2015).

Addison, Douglas, "Productivity Growth and Product Variety: Gains from Imitation and Education," Policy Research Working Paper No. 3023, World Bank (April 2003).

Agénor, Pierre-Richard, The Economics of Adjustment and Growth, Harvard University Press (Cambridge, Mas.: 2004).

—-, Public Capital, Growth and Welfare, Princeton University Press (Princeton, New Jersey: 2012).

— _ "Public Capital, Health Persistence and Poverty Traps." Journal of Economics, 115 (June 2015), 103-31.

Agénor, Pierre-Richard, and Joshua Aizenman, "Aid Volatility and Poverty Traps," Journal of Development Economics, 91 (January 2010), 1-7.

Agénor, Pierre-Richard, and Baris Alpaslan, "Infrastructure and Industrial Development with Endogenous Skill Acquisition," Working Paper No. 195, Centre for Growth and Business Cycle Research (October 2014).

Agénor, Pierre-Richard, and Otaviano Canuto, "Access to Finance, Product Innovation and Middle-Income Traps," Policy Research Working Paper No. 6767, World Bank (February 2014).

—_, "Middle-Income Growth Traps," Research in Economics, 69 (December 2015), 64160.

Agénor, Pierre-Richard, and Hinh T. Dinh, "Public Policy and Industrial Transformation in the Process of Development," Policy Research Working Paper No. 6405, World Bank (April 2013).

Agénor, Pierre-Richard, and Karim El Aynaoui, Morocco: Growth Strategy for 2025 in an Evolving International Environment, OCP Policy Center (Rabat: 2015).

Aghion, Philippe, and Peter Howitt, The Economics of Growth, MIT Press (Cambridge, Mass.: 2009).

Aghion, Philippe, Peter Howitt, and David Mayer-Foulkes, "The Effect of Financial Development on Convergence: Theory and Evidence," Quarterly Journal of Economics, 120 (January 2005), 173-222.

Aiyar, Shekhar, Romain A Duval, Damien Puy, Yiqun Wu, and Longmei Zhang, "Growth Slowdowns and the Middle-Income Trap," Working Paper No. 13/71, International Monetary Fund (March 2013). 
Amiti, Mary, and Jozef Konings, "Trade Liberalization, Intermediate Inputs, and Productivity: Evidence from Indonesia," American Economic Review, 97 (December 2007), 1611-38.

Athukorala, Prema-Chandra, and Wing Thye Woo, "Malaysia in the Middle-Income Trap," unpublished, Crawford School of Public Policy, Australian National University (March 2011).

Ayyagari, Meghana, Asli Demirgüç-Kunt, and Vojislav Maksimovic, "Firm Innovation in Emerging Markets: The Roles of Governance and Finance," Journal of Financial and Quantitative Analysis, 46 (September 2011), 1545-80.

Azariadis, Costas, "The Theory of Poverty Traps: What have we Learned?," in Poverty Traps, ed. by Samuel Bowles, Steven N. Durlauf, and Karla Hoff, Princeton University Press (Princeton, N.J.: 2006).

Azariadis, Costas, and John Stachurski, "Poverty Traps," in Handbook of Economic Growth, ed. by Philippe Aghion and Steven Durlauf, Vol. 1, North Holland (Amsterdam: 2005).

Bénassy, Jean-Pascal, and Elise S. Brezis, "Brain Drain and Development Traps," Journal of Development Economics, 102 (May 2013), 1-22.

Benhabib, Jess, Jesse Perla, and Christopher Tonetti, "Catch-up and Fall-Back through Innovation and Imitation," Journal of Economic Growth, 19 (March 2014), 1-35.

Brahmbhatt, Milan, and Albert Hu, "Ideas and innovation in East Asia," World Bank Research Observer, 25 (August 2010), 177-207.

Brown, James R., Gustav Martinsson, and Bruce C. Petersen, "Do Financing Constraints Matter for R\&D?," European Economic Review, 56 (November 2012), 1512-29.

Canuto, Otaviano, Mark A. Dutz, and José Guilherme Reis, "Technological Learning and Innovation: Climbing a Tall Ladder," in The Day after Tomorrow: A Handbook on the Future of Economic Policy in the Developing World, ed. by Otaviano Canuto and Marcelo Guigale, World Bank (Washington DC: 2010).

Cecchetti, Stephen G., and Enisse Kharroubi, "Why does Financial Sector Growth Crowd out Real Economic Growth?," Working Paper No. 490, Bank for International Settlements (February 2015).

Chen, Been-Lon, and Angus C. Chu, "On R\&D Spillovers, Multiple Equilibria, and Indeterminacy," Journal of Economics, (September 2010) 247-63.

Cherif, Reda, and Fuad Hasanov, "The Leap of the Tiger: How Malaysia Can Escape the Middle-Income Trap," Working Paper No. 15/131, International Monetary Fund (June 2015).

Chudik, Alexander, Kamiar Mohaddes, M. Hashem Pesaran, and Mehdi Raissi, "Is There a Debt-threshold Effect on Output Growth?," Working Paper No. 15/197, International Monetary Fund (September 2015).

Cingano, Federico, "Trends in Income Inequality and its Impact on Economic Growth," Social, Employment and Migration Working Paper No. 163, OECD (September 2014).

Commission on Growth and Development, The Growth Report: Strategies for Sustained Growth and Inclusive Development, World Bank (Washington DC: 2008).

Cornia, Giovanni A., "Inequality Trends and their Determinants: Latin America over 1990-2011," Working Paper No. 2012-09, World Institute for Development Economic 
Research (January 2012).

Czernich, Nina, Oliver Falck, Tobias Kretschmer, and Ludger Woessmann, "Broadband Infrastructure and Economic Growth," Economic Journal, 121 (May 2011), 505-32.

Dabla-Norris, Era, Alun Thomas, Rodrigo Garcia-Verdu, and Yingyuan Chen, "Benchmarking Structural Transformation across the World," Working Paper No. 13/176, International Monetary Fund (July 2013).

Daude, Christian, "Innovation, Productivity and Economic Development in Latin America and the Caribbean," Working Paper No. 288, OECD Development Centre (February 2010).

Dinopoulos, Elias, and Peter Thompson, "Endogenous Growth in a Cross-Section of Countries," Journal of International Economics, 51 (August 2000), 335-62.

Egawa, Akio, "Will Income Inequality cause a Middle-Income Trap in Asia?," Working Paper No. 2013/06, Bruegel (October 2013).

Eggertsson, Gauti B., and Neil R. Mehrotra, "A Model of Secular Stagnation," Working Paper No. 20574, National Bureau of Economic Research (October 2014).

Eichengreen, Barry, Donghyun Park, and Kwanho Shin, "When Fast Economies Slow Down: International Evidence and Implications for China," Asian Economic Papers, 11 (March 2012), 42-87.

—_, "Growth Slowdowns Redux," Japan and the World Economy, 32 (November 2014), $65-84$.

Engel, Eduardo, Ronald Fischer, and Alexander Galetovic, "Finance and Public-Private Partnerships," in Financial Flows Infrastructure Financing, ed. by Alexandra Heath and Matthew Read, Reserve Bank of Australia (Sydney: 2014).

Felipe, Jesus, Arnelyn Abdon, and Utsav Kumar, "Tracking the Middle-Income Trap: What is it, who is in it, and why?," Working Paper No. 715, Levy Economics Institute of Bard College (April 2012).

Felipe, Jesus, Utsav Kumar, and Reynold Galope, "Middle-Income Transitions: Trap or Myth?," Working Paper No. 421 (November 2014).

Flaaen, Aaron, Ejaz Ghani, and Saurabh Mishra, "How to Avoid Middle Income Traps? Evidence from Malaysia," Policy Research Working Paper No. 6427, World Bank (April 2013).

Gancia, Gino, and Fabrizio Zilibotti, "Horizontal Innovation in the Theory of Growth and Development," in Handbook of Economic Growth, Vol. 1A, ed. by Philippe Aghion and Steven Durlauf, North Holland (Amsterdam: 2005).

Ghatak, Maitreesh, "Theories of Poverty Traps and Anti-Poverty Policies," World Bank Economic Review, 29 (June 2015), 77-105.

Gill, Indermit, Homi Kharas, and others, An East Asian Renaissance: Ideas for Economic Growth, World Bank (Washington, DC: 2007).

Glass, Amy J., "Imitation as a Stepping Stone to Innovation," unpublished, Texas A\&M University (June 2010).

Goldberg, Pinelopi, Amit Khandelwal, Nina Pavcnik, and Petia Topalova, "Imported Intermediate Inputs and Domestic Product Growth: Evidence from India," Quartery Journal of Economics, 125 (November 2010), 1727-67. 
Grimalda, G, and M Vivarelli, "Is Inequality the Price to Pay for Higher Growth in MiddleIncome Countries?," Journal of Evolutionary Economics, 20 (June 2010), 265-306.

Guillaumont, Patrick, Caught in a Trap: Identifying the Least Developed Countries, Economica (Paris: 2009).

Halpern, Laszlo, Miklos Koren, and Adam Szeidl, "Imported Inputs and Productivity," unpublished, Central European University (September 2011).

Hanushek, Eric A., and Ludger Woessmann, "Schooling, Educational Achievement, and the Latin American Growth Puzzle," Journal of Development Economics, 99 (November 2012a), 497-512.

— - "Do better Schools Lead to more Growth? Cognitive Skills, Economic Outcomes, and Causation," Journal of Economic Growth, 17 (December 2012b), 267-321.

Hill, Hal, Tham S. Yean, and H. Ragayah, "Malaysia: A Success Story Stuck in the Middle?," World Economy, 35 (December 2012), 1687-711.

Hottenrott, Hanna, and Bettina Peters, "Innovative Capability and Financing Constraints for Innovation: More Money, more Innovation?," Review of Economics and Statistics, 94 (November 2012), 1126-42.

Im, Fernando G., and David Rosenblatt, "Middle-Income Traps: A Conceptual and Empirical Survey," Policy Research Working Paper No. 6594, World Bank (September 2013).

Inter-American Development Bank, "The Importance of Ideas: Innovation and Productivity in Latin America," in The Age of Productivity, ed. by Carmen Pagés, InterAmerican Development Bank (Washington DC: 2010).

Iwaisako, Tatsuro, "Technology Choice and Patterns of Growth in an Overlapping Generations Model," Journal of Macroeconomics, 24 (June 2002) 211-31.

Jimenez, Emmanuel, Vy Nguyen, and Harry A. Patrinos, "Human Capital Development and Economic Growth in Malaysia and Thailand," Policy Research Working Paper No. 6283, World Bank (November 2012).

Kasahara, Hiroyuki, and Joel Rodriguez, "Does the Use of Imported Intermediates Increase Productivity? Plant-Level Evidence," Journal of Development Economics, 87 (August 2008), 106-18.

Kejak, Michal, "Stages of Growth in Economic Development," Journal of Economic Dynamics and Control, 27 (March 2003), 771-800.

Kharas, Homi, and Geoffrey Gertz, "The New Global Middle Class: A Cross-Over from West to East," unpublished, Wolfensohn Center for Development at Brookings (March 2010).

Kuwahara, Shiro, "The Mechanics of Economic Growth through Capital Accumulation and Technological Progress," Japanese Economic Review, 58 (December 2007), 504-23.

—_, "Dynamical Analysis of the R\&D-based Growth Model with a Regime Switch," Journal of Economics, 108 (March 2013), 35-57.

Law, Siong H., and Nirvikar Singh, "Does too much Finance Harm Economic Growth?," Journal of Banking and Finance, 41 (April 2014), 36-44.

Lee, Il Houng, Murtaza Syed, and Liu Xueyan, "Is China Over-Investing and does it Matter?," Working Paper 12/277, International Monetary Fund (November 2012). 
Lee, Jong-Wha, and Kiseok Hong, "Economic Growth in Asia: Determinants and Prospects," Working Paper No. 220, Asian Development Bank (September 2010).

Lee, Jong-Wha, and Ruth Francisco, "Human Capital Accumulation in Emerging Asia, 1970-2030," Japan and the World Economy, 24 (March 2012), 76-86.

Lustig, Nora, Luis F. Lopez-Calva, and Eduardo Ortiz-Juarez, "Declining Inequality in Latin America in the 2000s: The Cases of Argentina, Brazil, and Mexico," Policy Research Working Paper No. 6248, World Bank (October 2012).

Menon, Jayant, and Woo, W T, "Malaysia Needs a New Economic Policy Regime to Revive Dynamic Growth," unpublished, Asian Development Bank (March 2014).

OECD, The OECD Innovation Strategy: Getting a Head Start on Tomorrow, OECD (Paris: 2010).

- - Perspectives on Global Development: Boosting Productivity to Meet the MiddleIncome Challenge, OECD (Paris: 2014).

Park, Albert, Gaurav Nayyar, and Patrick Low, Supply Chain Perspectives and Issues, World Trade Organization (Geneva: 2013).

Perez-Sebastian, Fidel, "Public Support to Innovation and Imitation in a Non-Scale Growth Model," Journal of Economic Dynamics and Control, 31 (December 2007), 3791-821.

Pritchett, Lant, and Lawrence H. Summers, "Asiaphoria Meets Regression to the Mean," Working Paper No. 20573, National Bureau of Economic Research (October 2014).

Quah, Danny T., "Galton's Fallacy and Tests of the Convergence Hypothesis," Scandinavian Journal of Economics, 95 (December 1993), 427-43.

Redding, Stephen, "Low-Skill, Low Quality Trap: Strategic Complementarities between Human Capital and R\&D," Economic Journal, 106 (January 1996), 458-70.

Rodrik, Dani, "Premature Deindustrialization," Working Paper No. 20935, National Bureau of Economic Research (February 2015).

Romer, Paul M., "Endogenous Technological Change," Journal of Political Economy, 98 (October 1990), s71-s102.

Sahay, Ratna, et al., "Rethinking Financial Deepening: Stability and Growth in Emerging Markets," Staff Discussion Note No. 15/08, International Monetary Fund (May 2015).

Samargandi, Nahla, Jan Firdmuc, and Sugata Ghosh, "Is the Relationship between Financial Development and Economic Growth Monotonic? Evidence from a Sample of Middle-Income Countries," World Development, 68 (2015), 66-81.

Stone, Susan, and Ben Shepherd, "Dynamic Gains from Trade: The Role of Intermediate Inputs and Equipment Imports," Trade Policy Paper No. 110, OECD (June 2011).

UNESCO, Higher Education in Asia: Expanding Out, Expanding Up, United Nations Publications (Paris: 2014).

UNIDO, Breaking In and Moving Up: New Industrial Challenges for the Bottom Billion and the Middle-Income Countries, Industrial Development Report, United Nations (Vienna: 2009).

— Networks for Prosperity: Connecting Development Knowledge Beyond 2015, United Nations (Vienna: 2012).

Vandenbussche, Jérôme, Philippe Aghion, and Costas Meghir, "Growth, Distance to Frontier and Composition of Human Capital," Journal of Economic Growth, 11 (June 2006), 
97-127.

Wang, Yin-Chi, and Ping Wang, "Barriers to Health and the Poverty Trap," Working Paper No. 19263, National Bureau of Economic Research (July 2013).

World Bank, Technology Diffusion in the Developing World, Global Economic Prospects Report (Washington DC: 2008).

, China 2030: Building a Modern, Harmonious, and Creative High-Income Society, World Bank (Washington DC: 2012).

, Financial Inclusion, Global Financial Development Report, World Bank (Washington DC: 2014)

Ye, Longfeng, and Peter E. Robertson, "On the Existence of a Middle-Income Trap," unpublished, University of Western Australia (June 2015).

Zhang, Hongsong, "Static and Dynamic Gains from Costly Importing of Intermediate Inputs: Evidence from Colombia," unpublished, University of Hong Kong (June 2014). 